\title{
CRIANÇA QUE VIRA PASSARINHO E VOA: IMAGENS DA INFÂNCIA E SUA POTÊNCIA NO DESFORMAR DA EDUCAÇÃO MATEMÁTICA
}

\author{
CHILD WHICH TURNS INTO A BIRD AND FLIES: IMAGES OF \\ CHILDHOOD AND THE POWER OF UNFORMED MATHEMATICS EDUCATION \\ NIÑO QUE SE CONVIERTE EN PÁJARITO Y VUELA: IMÁGENES DE LA \\ INFANCIA Y SU POTENCIA PARA DEFORMAR LA EDUCACIÓN MATEMÁTICA \\ AMANDA SILVA DE MEDEIROS ${ }^{1}$ \\ SUELY SCHERER ${ }^{2}$
}

\section{RESUMO}

Este artigo tem como objetivo problematizar elementos da Educação Matemática nos Anos Iniciais a partir/com imagens produzidas na infância. Esta problematização ocorre em meio a um compor com poesia, narrativa e diálogos com autores que versam sobre a infância e o lugar que ocupa na escola. Esse compor é direcionado pelos afetos causados por imagens produzidas com um celular na mão na procura de matemáticas por crianças de 6 e 7 anos em uma escola. Assim, relembramos algumas marcas desses encontros e, mobilizadas por elas, discutimos sobre 0 desformar que elas causam na matemática, na formação de professores, no currículo e em tantos outros elementos da educação. Com isso, somos mobilizadas a pensar essas imagens também na Educação Matemática e evidenciamos a necessidade cada vez mais forte de uma educação e de uma pesquisa que sejam infantes, assumindo o encantamento, o novo, que operem com potências e que se desformam com as crianças.

Palavras-chave: Pesquisa Infante. Educação Matemática. Anos Iniciais. Produções Imagéticas. Afeto.

\section{ABSTRACT}

This article aims to problematize elements of Mathematics Education in the Early Years from/ with images produced in childhood. This problematization happens among the composition with poetry, narrative and dialogues with authors that talk about childhood and the place it occupies in school. This composition is directed by the affections caused by pictures of children aged 6 and 7 years in a school, with a cell phone in hand, looking for Mathematics. Therefore, we remember some marks of these meetings and, mobilized by them, we discussed about the distortion they cause in Mathematics, in the training of teachers, in the curriculum and in many other elements of education. With that, we are mobilized to think these pictures also in Mathematics Education and we show the growing need for an education and research that are infants, assuming the enchantment, the new, that operate with powers and that unformed with children.

Keywords: Infant Research. Mathematics Education. Early Years. Imagetic Productions. Affection.

\section{RESUMEN}

Este artículo tiene como objetivo problematizar los elementos de la Educación Matemática en los Primeros Años de la escuela básica a partir de/con imágenes producidas en la infancia. Esta problematización ocurre en medio de una

1 Doutoranda do Programa de Pós-Graduação em Educação Matemática da Universidade Federal de Mato Grosso do Sul, bolsista CAPES. E-mail: amandamedeiros94@hotmail.com. Orcid: https://orcid.org/0000-0003-2525-0877.

2 Doutora em Educação (currículo) pela PUCSP, professora associada da Universidade Federal de Mato Grosso do Sul. E-mail: suely.scherer@ ufms.br. Orcid: https://orcid.org/0000-0002-2213-3803. 
composición con poesía, narrativa y diálogos con autores que tratan sobre la infancia y el lugar que ocupa en la escuela. Esta composición está impulsada por los afectos causados por las imágenes producidas con un teléfono celular en la mano, en busca de matemáticas por niños de 6 y 7 años en una escuela. Así, recordamos algunas marcas de esos encuentros y movilizadas por ellas, discutimos sobre el deformar que ellas causan en las matemáticas, en la capacitación de los docentes, en el plan de estudios y en muchos otros elementos de la educación. Con eso, somos movilizados para pensar estas imágenes también en la Educación Matemática al mostrar la creciente necesidad de una educación e investigación que sean infantes, asumiendo el encantamiento, lo nuevo, que operen con potencias y que se deforman con los niños.

Palabras-clave: Investigación infante. Educación Matemática. Años iniciales en la Escuela Básica. Producciones Imagéticas. Afecto.

\section{TRAVESSIA}

Penso que devemos conhecer algumas poucas cousas sobre a fisiologia dos andarilhos. Avaliar até onde 0 isolamento tem o poder de influir sobre os seus gestos, sobre a abertura de sua voz, etc. Estudar talvez a relação desse homem com as suas árvores, com as suas chuvas, com as suas pedras. Saber mais ou menos quanto tempo 0 andarilho pode permanecer em suas condições humanas, antes de se adquirir do chão a modo de um sapo. Antes de se unir às vergônteas como as parasitas. Antes de revestir uma pedra à maneira do limo. Antes mesmo de ser apropriado por relentos como os lagartos. Saber com exatidão quando que um modelo de pássaro se ajustará à sua voz. Saber o momento em que esse homem poderá sofrer de prenúncios. Saber enfim qual o momento em que esse homem começa a adivinhar (BARROS, 2015, p. 84).

As palavras que colocamos aqui não são um começo, apesar de iniciarem a escrita deste artigo. A intenção aqui é fazer ressoar em quem lê um pouco dos afetos que direcionam essa escrita. Logo, o que é colocado nessas linhas não é início, nem fim, mas algo entre os dois, em meio a travessia (RIBETT0, 2016). E para que 0 afeto chegue em quem lê, ele precisa estar aqui, em um rompante, direcionando as palavras que são expulsas, que imploram para sair, para dizer um pouco de experiências de duas pesquisas que se entrelaçam.

Assim, esta escrita se dá na passagem, relembrando os momentos que dispararam nossos afetos e compondo ${ }^{3}$. Compondo com poesia, narrativas, problematizações e com leituras que têm nos mobilizado a pensar sobre imagens, infância e seu lugar na educação.

Em 2017 uma das autoras deste texto adentrou uma sala de aula do $1^{0}$ ano do Ensino Fundamental com um celular na mão e a intenção de que crianças com 6 e 7 anos de idade gravassem, pelos espaços da escola, o que consideravam matemática. As imagens ${ }^{4}$ produzidas por essas crianças mudaram não só a pesquisa de mestrado que estava sendo realizada naquele período, mas deram início a outra, de doutorado, que se coloca em movimento neste momento e que se propõe a pensar os afetos que nos causaram (e ainda causam) abalo. Imagens de infância, na infância, sobre escola, matemáticas e... outras coisas também.

3 Assumindo esse compor, esta escrita terá momentos de narração na primeira pessoa do singular, ao relembrar momentos em que uma das autoras do texto teve contato com as crianças e suas imagens, em um exercício de narrativa autobiográfica. Outras vezes, a narração será na primeira pessoa do plural, por dizer do momento de agora, da travessia, em que as duas autoras compõem este texto.

4 Declaramos que temos direitos de exibição das imagens produzidas no contexto de pesquisa. 
Assim, este artigo tem como objetivo problematizar elementos da Educação Matemática a partir/com imagens produzidas na infância. Imagens produzidas em uma pesquisa de mestrado já finalizada, mas que movimentam algumas discussões que serão colocadas aqui e que direcionam uma pesquisa de doutorado em desenvolvimento. Uma composição guiada por marcas, se distanciando de uma língua fria, se propondo a escrever.... e contar com poemas, narrativas e afetos.

Esta composição se dá em um movimento cartográfico, de encontros, de marcas. Nesse sentido, não buscamos analisar as imagens aqui apresentadas, mas sim, compor com os afetos que elas disparam em nós. Assim, buscamos um movimento que "ao invés de somente explicar, de desdobrar a dobra, seu olhar e escrita multi/implicam o mundo" (COSTA, 2014, p. 72). Então, as imagens são entradas para produções de problematizações, de deslocamentos, de rupturas. Esses movimentos no texto são disparados muitas vezes por perguntas, não com a intenção de que o leitor necessariamente responda, mas sim como potências para romper os padrões do natural, da pressuposição de uma necessidade de respostas que, e sim como uma fissura que nos força a questionar fatos dos quais sempre parecemos ter certeza (RIBETTO; DIAS, 2020). Seguimos então, compondo em encontros que ainda acontecem.

\title{
MINÚCIAS E MARCAS DE UM ENCONTRO COM IMAGENS E INFÂNCIA
}

\author{
A ciência pode classificar e nomear os órgãos de um sabiá \\ mas não pode medir seus encantos \\ A ciência não pode calcular quantos cavalos de força existem nos encantos de um sabiá. \\ Quem acumula muita informação perde 0 condão de adivinhar: divinare. \\ Os sabiás divinam (BARROS, 1996, p. 56).
}

É domingo a tarde e estou sentada em frente ao computador. A qualificação passou e 0 incomodo é maior do que antes dela. As imagens estão lá, passando e passando, ignorando que meus olhos acompanham tudo, mas não veem nada. Olho de novo as observações. Olho para 0 texto produzido por mim. Há um capítulo todo sobre infância, crianças, mas nada ali parece me ajudar com os vídeos delas. Começo de novo, procurando a matemática que pedi para que gravassem. Dou play. São mais de cinco minutos de gravação. Ouço gritos, risadas, assuntos aleatórios. Filma os pés, as mãos, a corrida, o futebol na quadra. Teto, chão, teto, chão, gargalhadas, pés. Chega já, alguém diz. Escuro.

Figura 1 - Pés parados ou em movimento?

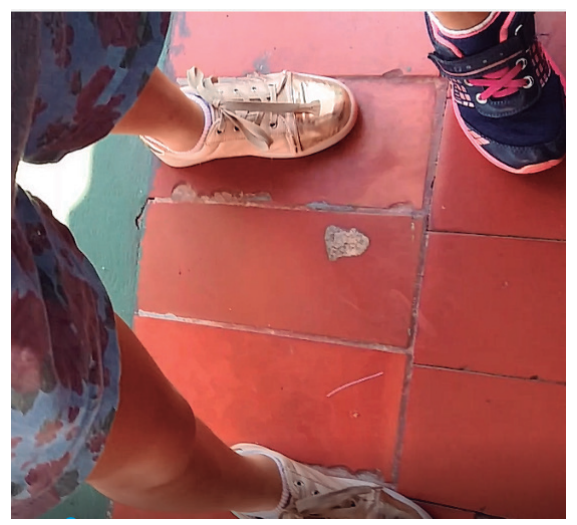

Fonte: Das Autoras 5 .

5 As imagens que têm com fonte: "Das Autoras" se referem a produções feitas pelas crianças na pesquisa de mestrado que originou este artigo, mas que não foram usadas no texto da dissertação. 
Vou procurar algum texto para ler, outra coisa que me ajude, porque preciso de um acalento. Há um arquivo de um livro de Manoel de Barros e abro. Uma amiga me falou sobre ele. Decido tentar. Vou correndo os olhos pelas páginas, diminuindo a velocidade, e parando em alguns momentos. Parando em muitos momentos. Não sei quanto tempo parei. Nem preciso saber. Não consigo descrever a sensação daquele momento, de ler aquelas linhas e pensar nas crianças, nos vídeos.

Posso classificar, o que está ali, mas não medir essas sensações, essas vertigens, esses encantos. Será que eu tenho acumulado muita informação? Começo a pensar que talvez 0 teto, 0 chão e os pés sejam bons para poesia. E para pesquisa também.

$$
\star \star \star
$$

Desde o dia narrado acima, do encontro com Manoel de Barros e com suas falas sobre infância, as imagens produzidas pelas crianças ganharam outra dimensão. Os encontros com elas e com as imagens produzidas por elas foram (re)visitados e ainda são. Visitas sem objetivo traçado ou procura específica. São visitas para estar ali e sentir. Porque é visita de infância e infância não é fase da vida, é estado de existência. É estado de existência humana que gagueja, que mal consegue falar, que se encanta, suspira, treme.

0 momento pré-verbal da palavra, a experiência de experimentar o mundo sem necessidade de nomeá-lo, um 'des-ver', um 'des-velar' o mundo, um 'des-falar' o mundo. Não se trata de um retorno à infância, onde ainda não há fala, mas um não falar, um perceber aquilo que é não saber falar, gaguejar, tremer a voz, perder a fala diante do encantamento do novo, o qual se inicia na infância (LEITE, CHISTÉ, 2014, p. 272).

Infância que mostra os pés, 0 chão, o teto, que dá vertigem e diz que não quer mais gravar. Infância que usa o corpo para outras funções que não são dele (que nós, adultos, não consideramos ser, na verdade). Que ao gravar matemática mostra cavalos, amarelinha, borboletas. E mal fala, porque quer correr, gravar, brincar (MEDEIROS, 2018).

As memórias desses encontros com as crianças, com Manoel de Barros e com autores que discutem infância e suas imagens, nos movimentam a pensar na necessidade de problematizar posturas ao se pesquisar na infância e com produções da infância, além de pensar qual o espaço dessa infância na Educação Matemática. Essas mobilizações são movimentadas pelos afetos dessas crianças, povoadas de infância, que nos deixaram marcas, que ainda fazem ressoar em nós suas minúcias (CHISTÉ, 2015). Minúcias de encontros entre crianças, pesquisas e poesia.

Quem sabe possamos encontrar um novo início para outra ontologia e outra política da infância naquela que já não busca normatizar o tipo ideal ao qual uma criança deva se conformar, ou o tipo de sociedade que uma criança tem que construir, mas que busca promover, desencadear, estimular nas crianças, e também em nós mesmos, essas intensidades criadoras, disruptoras, revolucionárias, que só podem surgir da abertura do espaço, no encontro entre o novo e o velho, entre uma criança e um adulto (KOHAN, 2007, p. 97-98).

Pensar essa política da infância que é revolucionária não é confortável, porque sempre buscamos as normatizações. Buscamos padrões porque também fomos docilizados e habituados a isso. 
Porque quando nós éramos crianças foi dito o que devíamos ser, o que fazer, o que era esperado. E porque se permitir experienciar essa intensidade criadora também expõe, é desacostume e dói (ROLNIK, 1993).

Figura 2 - Braços que resistem.

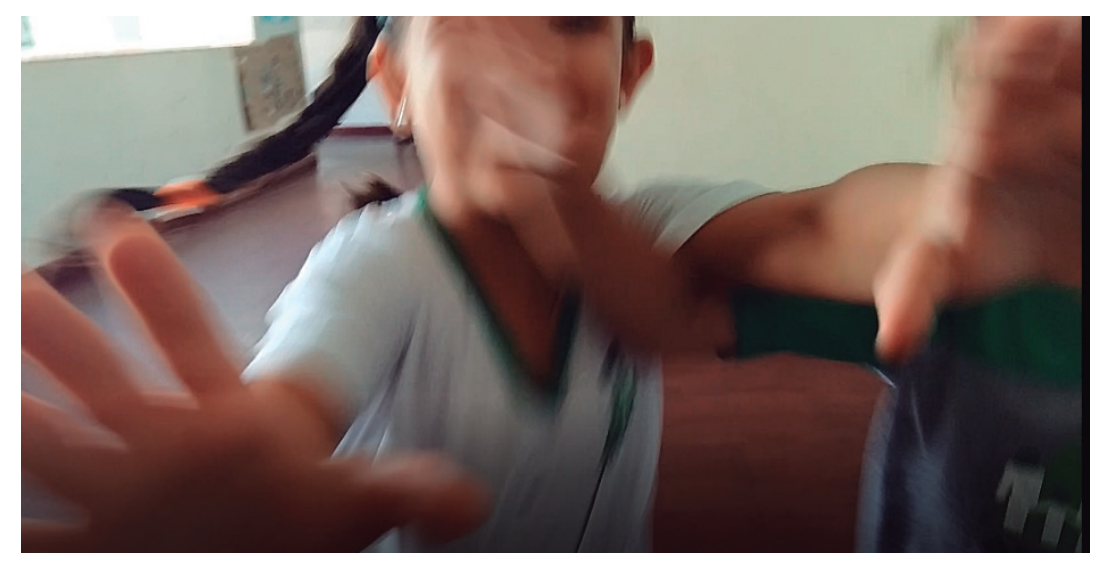

Fonte: Medeiros (2018, p. 21).

A partir desses afetos, começamos a pensar então nesse processo, nesses movimentos, nas minúcias que são causadas por revolução, por essa inventividade. Barros (2015) nos diz de um processo que as crianças causam no mundo, pois elas têm "a liberdade para cultivar uma visão torta das coisas. Seu olhar é sinuoso, e não reto (BARROS, 2015, p. 14). Podemos nós, adultos, não usar 0 traço acostumado também?

Voltamos então à tarde de domingo que inicia esse trecho. Ao ver as imagens, permitir as afetações, nos tornamos resistência. Resistência à uma única forma, um único padrão, uma única resposta. Resistência à matemática (única e estática). Resistência a transformar a vertigem, os sapatos, as risadas em uma coisa ou outra. 0 desformar é então isto e aquilo e mais aquele outro. É problematização em meio a teorematização constante que ocorre nas pesquisas, na escola, na formação, no currículo e que, pouco a pouco, dociliza os corpos que se movimentam com braços para todos os lados (CLARETO, 2013; MEDEIROS, 2018).

As crianças e as infâncias vão além da realidade vivida, elas transveem o mundo, quebram as regras estabelecidas. Elas têm 0 poder de mudar a ordem das coisas, de virá-las pelo avesso, de profanar 0 uso e des-usos do que é sacralizado, de des-criar o que existe. É somente profanando que as crianças e as infâncias resistem a instrumentalização e a docilização de seus corpos, de seus pensamentos de sua linguagem (CHISTÉ; LEITE, 2014, p. 4060).

As minúcias, 0 desacostume que essas imagens produzidas por crianças de 6 e 7 anos nos causaram nos movimentam então a pensar: 0 que podem essas imagens no espaço escolar? Como elas ressoam nos corpos daqueles que habitam o espaço escolar? 0 quanto de desformar cabe na escola? 0 quanto de infância cabe na sala de aula, na educação? 


\section{VERTIGEM, GARGALHADA E MOVIMENTO: IMAGENS, INFÂNCIA E TRAÇOS DESACOSTUMADOS}

A gente não gostava de explicar as imagens porque

explicar afasta as falas da imaginação.

A gente gostava dos sentidos desarticulados como a

conversa dos passarinhos no chão a comer pedaços de

mosca.

Certas visões não significavam nada mas eram passeios verbais.

A gente sempre queria dar brazão às borboletas.

A gente gostava bem das vadiações com as palavras do que das prisões gramaticais.

Quando o menino disse que queria passar para as palavras suas peraltagens até os caracóis apoiaram.

A gente se encostava na tarde como se a tarde fosse um poste.

A gente gostava das palavras quando elas perturbavam os sentidos normais da fala.

Esses meninos faziam parte do arrebol como os passarinhos (BARR0S, 2015, p. 120).

Não sei que horas são, mas a luz que entra pelo vitrô da janela já está enfraquecida, o que indica que a tarde daquele domingo está acabando. Nem dou atenção aquilo, estou vendo os vídeos, rindo com as crianças, sentindo tontura com o balançar da câmera. Passo para o próximo vídeo. Eles dizem que amam matemática, falam sobre profissões, o que querem ser quando crescer, e correndo pela escola, encontram um cavalo pintado em um quadro. Ao ver aquela cena, ouvir aquele diálogo, tenho a sensação de ter sido derrubada.

- Matheus: Eu adoro andar de cavalo!

- Maria: Eu adoro andar de cavalo!

- Guilherme: E eu adoro andar de cavalo também!

- Laura: E eu também adoro andar de cavalo, mas cavalo é muito grandão.

- Matheus: E eu adoro laçar também. Ir no clube do laço.

- Laura: E eu adoro ser professora de matemática também. Matemática é continha.

- Matheus: Eu adoro é esse cacto aqui.

-Maria: Matemática é de primeiro até terceiro. Construção e pintar. Eu adoro matemática bastantão.

- Laura: Eu também adoro, vou ser professora de matemática quando crescer. E também vou ser médica. Você não disse o que é matemática, Matheus!

- Matheus: Eu não sei o que é não, já falei que gosto do cacto! 
Figura 3 - Eu adoro andar de cavalo!

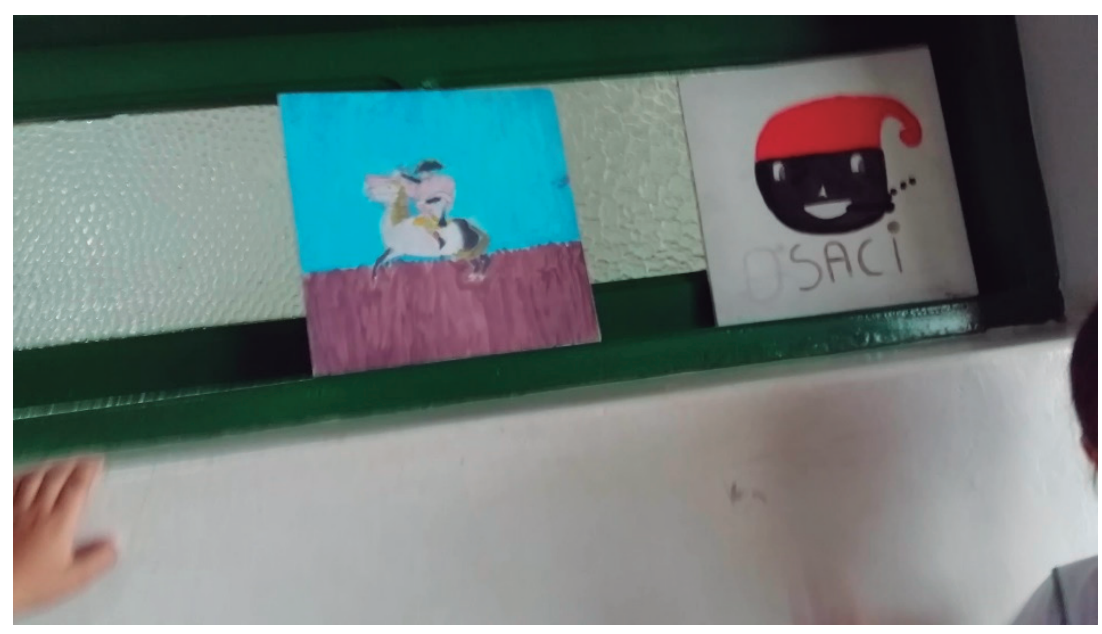

Fonte: Medeiros (2018, p. 87).

Olho para a imagem do cavalo por um tempo. Depois assisto o vídeo de novo. Sinto vontade de dizer a profissão que eu queria ter, e de dizer que não, eu não gosto de andar a cavalo. As imagens me fazem ter vontade de ter 6 anos de novo, de brincar e correr. De criançar. Não sei explicar como, mas que bom que não sei, pois assim não afasto as falas da imaginação.

$$
\star \star \star
$$

0 que pode a imagem?

A infância, gaguejante, fase que se coloca na fronteira, pode também se mostrar nas imagens. Imagens que nos carregam na travessia, na reticência, em devir. Imagens que nos desestabilizam, que causam no corpo incômodo. Imagens que se tornam resistência à docilização dos braços, das pernas, das gargalhadas, das conversas sobre cavalos e cactos em meio a matemática que é procurada (e será que achá-la era o mais importante?). Imagem que é potência, devir (LEITE, 2013).

As imagens/filmagens produzidas pelas crianças abre a possibilidade de olhar 0 corpo, a exposição dos corpos, movimentos, corpos em movimentos, corpos deslocados, corpos que falam, vibram, gritam, corpos produtivos, corpos produtivos lançados em aventuras intelectuais em outros tempos, tempos kairológicos, tempos aiônicos, tempo acontecimento, tempo experiência, tempo não previsto, tempo indecisivo, tempo indefinido. As imagens/filmagens produzidas pelas crianças nos levam a pensar na existência de duas infâncias: uma infância majoritária, que segue o tempo da progressão sequencial e funcional e que se educa de acordo com um modelo pré-estabelecido. E outra que poderiamos dizer, a infância minoritária, que vem a ser infância como experiência, como acontecimento, como resistência, como revolução e como criação (CHISTÉ. LEITE, 2014, p. 4060). 
Figura 4 - Resistência

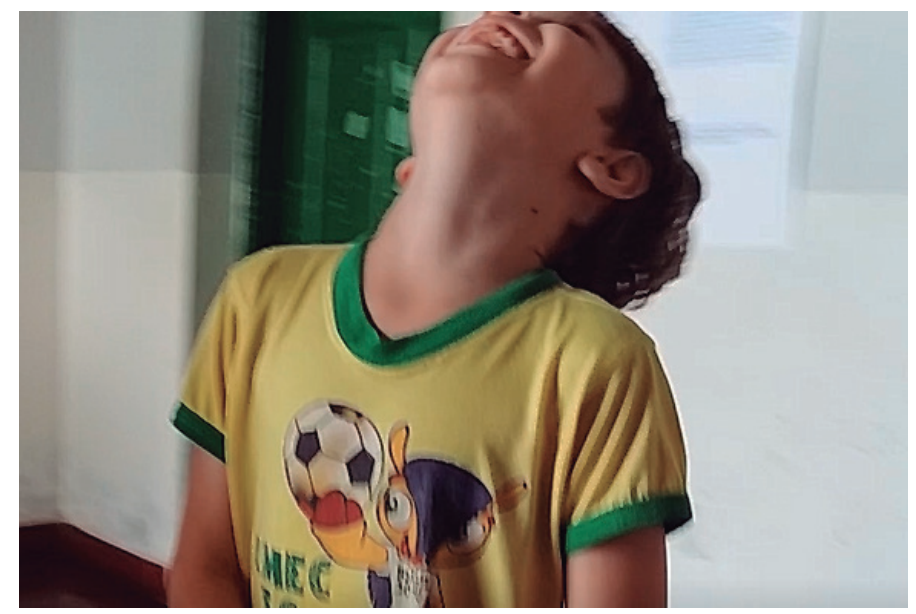

Fonte: Medeiros (2018, p. 111).

Esta infância minoritária desformou a pesquisa, a matemática, a sala de aula, a escola. Desformou as verdades que nós, adultos, buscávamos e prevíamos. As imagens tornaram-se fala gaguejante, o tartamudo de Barros (2015), que causa perda de voz porque causa estranhamento, mas também afeta.

As imagens dessas crianças são também escritas delas, são também composições. São falas do corpo, das marcas que trazem, dos afetos sentidos. Ribetto (2016) fala de escrever o que nos toca, apaixonadamente. As imagens produzidas pelas crianças (as que estão neste texto, as muitas outras que não cabem aqui) são escritas apaixonadas, sobre escola, matemática, sala de aula, infância.

0 que pode a imagem?

Pode desacostumar, incomodar, pode tanto....

Imagens que deixam minúcias, uma captura de um momento entre milhares de outros, restos de tempo, de corpos. Imagens que mesmo paradas e em silêncio, movimentam, gritam (WUNDER, 2007). Imagens que são despalavras, que são coisas e mais coisas entrelaçadas, sem medida, mas inundadas de afeto.

Hoje eu atingi o reino das imagens, o reino da despalavra.

Daqui vem que todas as coisas podem ter qualidades humanas.

Daqui vem que todas as coisas podem ter qualidades de pássaros.

Daqui vem que todas as pedras podem ter qualidades de sapo.

Daqui vem que todos os poetas podem ter qualidades de árvore.

Daqui vem que os poetas podem arborizar os pássaros.

Daqui vem que todos os poetas podem humanizar as águas. 


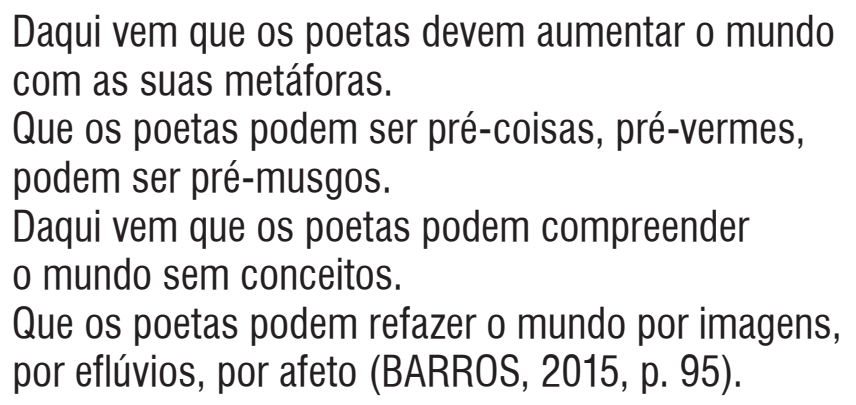

0 que pode a imagem?

Pode então desestabilizar nossas certezas, repletas de infância. Pode nos fazer estar no mundo, na infância, na escola. Não compreendê-la, mas estar nela, na passagem, na travessia. No aqui.

As imagens e os afetos produzidos por elas nos ajudam a dizer de uma infância minoritária. Mas quando a gravação acaba, a câmera é desligada, é a infância maioritária que predomina? Onde a resistência, a criação desses corpos se colocam na escola? 0 que acontece quando 0 que buscamos na imagem é 0 antes, o depois, a resposta?

\title{
O QUE PODEM IMAGENS DA INFÂNCIA DESFORMAR EM CURRÍCULOS, FORMAÇÕES, MATEMÁ- TICAS E...?
}

\begin{abstract}
Nosso Profe. de latim, Mestre Aristeu, era magro e do Piauí. Falou que estava cansado de genitivos dativos, ablativos e de outras desinências. Gostaria agora de escrever um livro. Usaria um idioma de larvas incendiadas. Epa! o profe. falseou-ciciou um colega. Idioma de larvas incendiadas! Mestre Aristeu continuou: quisera uma linguagem que obedecesse a desordem das falas infantis do que as ordens gramaticais. Desfazer o normal há de ser uma norma. Pois eu quisera modificar nosso idioma com as minhas particularidades. Eu queria só descobrir e não descrever. 0 imprevisto fosse mais atraente do que 0 dejá visto. 0 desespero fosse mais atraente do que a esperança. Epa! 0 profe. desalterou de novo - outro colega nosso denunciou. Porque o desespero é sempre o que não se espera. Verbi gratia: um tropicão na pedra ou uma sintaxe insólita. 0 que eu não gosto é de uma palavra de tanque. Porque as palavras do tanque são estagnadas, estanques, acostumadas. E podem até pegar mofo. Quisera um idioma de larvas incendiadas. Palavras que fossem de fontes e não de tanques (BARROS, 2006, p. 32).
\end{abstract}

Já está escuro lá fora. Os vídeos terminaram há um bom tempo. Me levantei, estiquei as pernas, pensei em me sentar no sofá e olhar para a televisão até o sono chegar. Afinal, amanhã é segunda e a semana vai ser difícil (e qual não é? ou são difíceis e fáceis...). Mas não consigo. Estou de volta à mesa, olhando para 0 computador com a cabeça fervendo. Assisti todos os vídeos, alguns mais de uma vez. Não anotei nada, não transcrevi nada. Só senti e continuo sentindo. Mas não é fácil esse processo. Mesmo mobilizada pelos poemas, vez ou outro eu queria pegar a caneta, marcar algumas coisas. Talvez eu faça isso amanhã. Hoje não. Não me permito isso hoje, vou me permitir um desacostume.

Há um incomodo nesse movimento, mas um maior está reverberando em mim. Assisto um dos vídeos de novo, o de Heitor. 
- Heitor: Eu tô achando legal procurar matemática. Não tô achando matemática, mas tô achando legal.

- Duda: Eu acho que matemática é número. Mas não tem número pra mostrar. Só os que têm nas salas: $1^{\circ}$ ano, $4^{\circ}$ ano, $5^{\circ}$ ano. Filme Felipe!

A câmera mostra as portas das salas em um movimento "bem rapidão", segundo Felipe.

- Heitor: Ué, só isso que é matemática? Eu já sei, eu já sei!

Heitor sai correndo, o celular cai da mão de Felipe, mas (por um milagre) não para de gravar.

- Felipe: Ui,ui,ui, caiu o celular

- Heitor: Eu lembrei. Filme bem aqui a matemática.

Figura 5 - Matemática

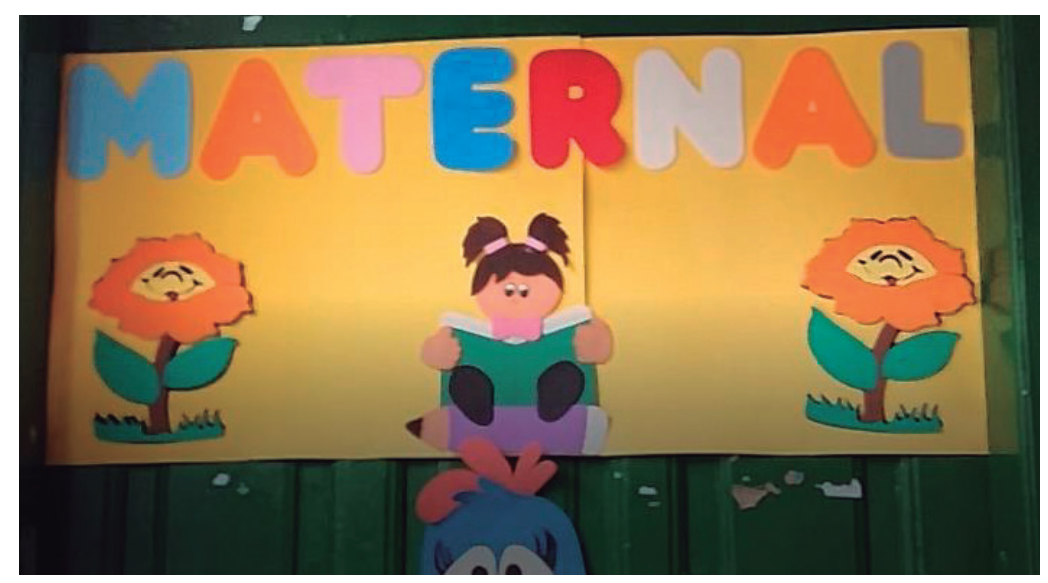

Fonte: Medeiros (2018, p. 101)

-Heitor: Ma-ter-nal e os desenhos.

- Duda: Isso aí é matemática?

- Felipe: Eu não sei não.

- Heitor: É sim, igual os números são matemática. É a mesma coisa.

No vídeo deste grupo eu apareço, quando eles me devolvem o celular o aparelho ainda está gravando e Duda reclama para mim:

- 0 Heitor que disse que era matemática, mas eu não achei que era matemática.

- Heitor: É matemática sim, porque é que nem aquele dia que a professora falou pra gente inventar uma estorinha. Eu inventei também que era matemática.

- Duda: Agora a gente vai tirar zero.

Penso no poema de Manoel de Barros e em Heitor, com seu idioma de larvas incendiadas, criando uma matemática outra com suas particularidades. E penso em Duda, na sua preocupação com a nota. Sua palavra já está acostumada, é de tanque, do que já foi visto.

Quem foi que fez isso com ela? 
Nossa palavra é acostumada, é tanque, não tem larvas incendiadas. A sua também? Nosso idioma é docilizado, fechado, formado. As coisas têm suas funções e pronto. Já as crianças, com suas potências, dão funções às coisas que não são delas, incendeiam, problematizam. Desformam (BARROS, 2015).

Pensar então os anos iniciais do Ensino Fundamental e a Educação Infantil e seus movimentos não necessita dessas funções outras, já que as crianças, que habitam e são habitadas por este espaço, desformam? Um desformar citado por Barros (2015, p. 83).

Aprendi com Rômulo Quiroga (um pintor boliviano):

A expressão reta não sonha.

Não use 0 traço acostumado.

A força de um artista vem das suas derrotas.

Só a alma atormentada pode trazer para a voz um

formato de pássaro.

Arte não tem pensa:

0 olho vê, a lembrança revê, e a imaginação transvê.

É preciso transver o mundo.

Isto seja:

Deus deu a forma. Os artistas desformam.

É preciso desformar o mundo:

Tirar da natureza as naturalidades.

Fazer cavalo verde, por exemplo.

Fazer noiva camponesa voar - como em Chagall.

Agora é só puxar o alarme do silêncio que eu saio por aí a desformar.

Mas 0 que significa esse desformar? 0 que ele nos possibilita pensar? No livro a Lógica da Sensação, Deleuze também cita os artistas para falar sobre desformar e nos direciona sobre suas possiblidades. 0 autor fala sobre as pinturas de Francis Bacon que constrói suas obras impelido por forças, sensações, afetos que descolam e potencializam pinturas que fogem ao habitual, que rompem a ordem das coisas, que tiram a precisão das formas. Pinturas que contrastam com uma simetria, com uma forma naturalizada e confortável (BRITO, 2016). 
Figura 5 - Três Figuras de Francis Bacon.

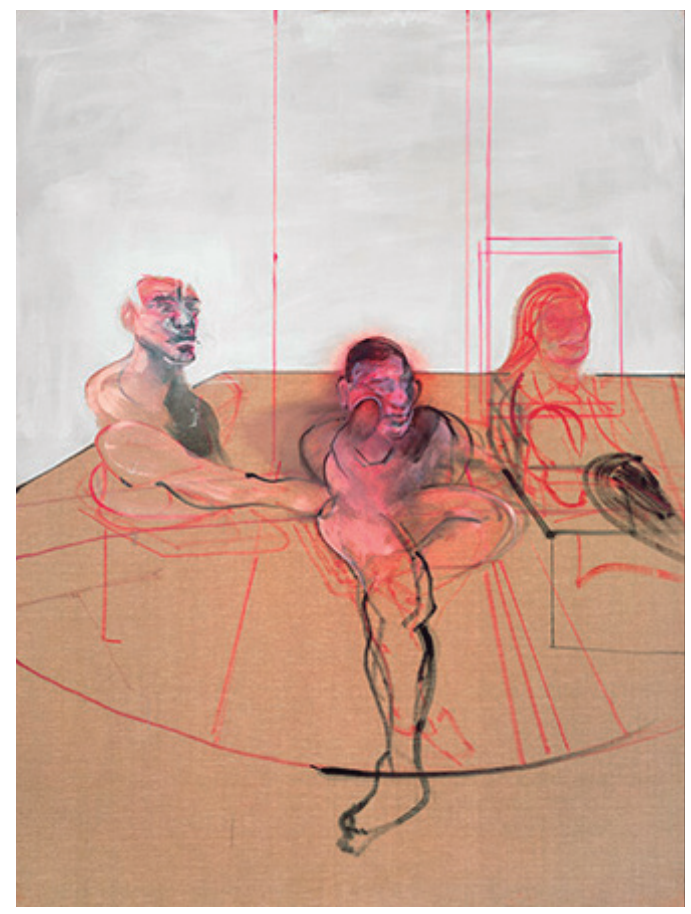

Fonte: https://francis-bacon.com/artworks/paintings/three-figures.

A pintura de Francis Bacon e o modo como ela é construída nos faz lembrar as imagens das crianças, que incomodam, desabituam, são imprevisíveis. Imagens que são insubordinadas às perguntas lançadas, ao produto final. Imagens que se constituem no sendo, no presente, no momento. Imagens de resistência. As crianças são também artistas, elas também desformam.

Figura 6 - Um "olá" desfocado.

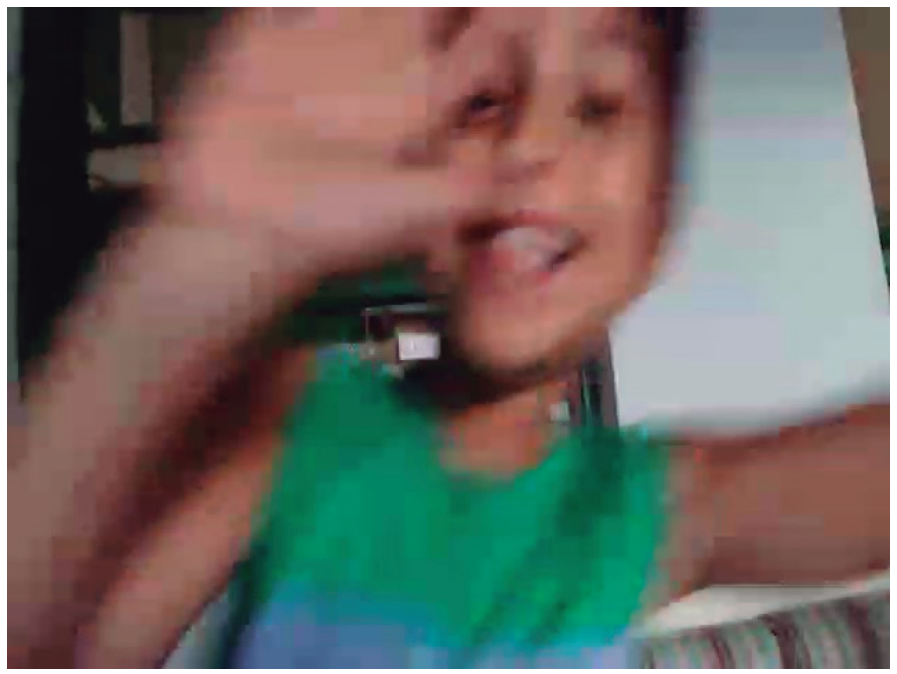

Fonte: Das Autoras. 
Essa resistência é potência de criação, de experiência, de (re)aprender, de (trans)formar. Acontece que a fala de Duda ("Agora a gente vai tirar zero"), assim como imagens e procuras produzidas pelas crianças, indicam que essa resistência é rapidamente diluída, subordinada a currículos que engessam e dão forma, docilizada por posturas construídas em meio a uma formação fechada.

Diante desse cenário, o que essas falas, o que essas imagens, fazem ressoar em nós professoras, pesquisadoras?

Nesse sentido, a necessidade de refletir e problematizar estas e outras questões tem nos mobilizado a cada vez mais buscar ocupar/habitar o espaço da escola e conviver com as crianças e suas potências. As duas pesquisas citadas no início desse texto vêm compondo estas linhas até agora. Mas este é o momento em que é preciso dizer dos afetos desta pesquisa que se findou e que estão impulsionando a pesquisa que está em desenvolvimento ${ }^{6}$. Afetos que nos abalam e que nos inundam de perguntas. Se serão respondidas? Não sabemos. Mas elas nos conduzem a querer pesquisar.

Talvez as perguntas mais fortes neste momento (de escrita, de agora, de passagem) sejam: até onde/até quem o desformar pode e chega? Até que ponto ele consegue tirar as formas na/da escola? Mais especificamente, como esse desformar ressoa em currículos, em formações de professores, em matemáticas?

Penando nas produções destas crianças, nas imagens feitas por elas, a matemática está longe de se apresentar da maneira como queríamos e esperávamos. Ma-ter-nal, dito de forma pausada, para dar ênfase, uma matemática inventada por Heitor. Que potência de criação podemos dar a Heitor quando ele nos diz isso? A grande questão aqui está na forma como lidamos com isso. 0 infante, 0 desformar de Barros (2015) chega até nós?

Talvez não, porque nossa primeira reação (e segunda, e terceira, e quarta, ...) é colocar o maternal de Heitor em alguma gaiola epistemológica. É olhar para a discussão sobre cavalos, cactos e descartá-la. Somos também repletos de formas, docilizados, reféns de uma lógica binária que só considera o isto ou aquilo. Nunca o "e". No pensamento complexo, fugindo da lógica binária, a matemática pode ser muitas coisas... e cacto, e cavalos, e ma-ter-nal, e... (MORAES, 2010).

Outras possibilidades que disparam potências criadoras, o novo, mas que não ocorre porque na educação (e também na vida) o novo é acolhido pelo velho que quer transformá-lo em um igual. Potências criadoras que por vezes são adaptadas, aprisionadas até se tornarem homogêneas, genéricas, tratadas como uma forma de infantilização que, na verdade, é o olhar de cima: 0 adulto ensina a criança a ser a criança que ele espera. Os fluxos então, se perdem (KOHAN, 2003).

É preciso então pensar esse desformar na educação e considerar esses movimentos heterógenos de crianças.

Não se trata de transformar o mundo, mas de acolher, ou não, a novidade dos novos; perceber, ou não, sua alteridade; propiciar, ou não, essa pluralidade; dar espaço, ou não, à sua diversidade. Em última instância, uma educação transformadora é aquela que transforma o que pensamos, 0 que somos, o que fazemos numa relação aberta com a novidade dos novos (KOHAN, 2003, p. 112).

6 No momento de escrita desse artigo estamos em plena pandemia do Covid-19. Como tantos outros planos, essa situação nos impediu de estar no espaço físico da escola e escrever estas linhas já mobilizadas por vivências de lá. Enquanto não podemos estar nesse espaço, produzimos com os afetos de reflexões de leituras e de outros momentos em que estivemos com as crianças. 
0 quanto consideramos, o quanto percebemos, o quanto nos permitimos (re)aprender com as crianças? 0 quanto nós, ao lidarmos com 0 criançar desses novos integrantes do espaço da escola possibilitamos multiplicidades? Como permitir isso?

Talvez desformando a Educação Matemática, em um movimento no qual

o propósito é tornar sensíveis as forças que atravessam um corpo que não aguenta mais a subordinação, 0 cansaço negativo asfixiante da educação fria, sem vida e moribunda. Uma educação por esses modos não está subordinada à representação, à adequação da verdade, antes disso, os instrumentos para pontuar os traços vitais para educação percorrem movimentos de forças, de resistências, que podem deformar a forma estabelecida por currículos escolares, saberes prontos, conhecimentos interpretados que desejam modulação universal. Com isso, seria possível compor cores novas e vibrantes ao novo corpo que deseja nascer, um corpo alegre, desejante, movimentado por seus devires reais, percorrido por sensações nervosas e por desejos revolucionários (BRIT0, 2016, p. 92).

Mas como operar com isso? Como permitir que nossos corpos se afetem e se movimentem com as crianças? Imagens.

Aos nos depararmos com as produções imagéticas das crianças temos visto a possibilidade de pensarmos essa desformação a partir/com elas. Processos de desformação de currículos, de escolas, de formações de professores, de matemáticas, de pesquisas...

É preciso ressaltar que esse movimento não é fácil, é inconstante e dolorido. Não estamos habituados a usar traços desacostumados, a nos permitirmos não buscar classificar quantos cavalos de força tem 0 canto de um sabiá. Mas, pensando nessa educação desformadora, é preciso tentar (BARROS, 2015).

Até então nosso contato se dá com imagens produzida por alunos do $1^{\circ}$ ano do Ensino Fundamental, que já estão habituados ao espaço escolar há cerca de dois anos. Voltamos nossos olhares agora para o espaço da Educação Infantil, para os movimentos de crianças que estão iniciando sua jornada escolar obrigatória, crianças de 4 e 5 anos, adentrando a um espaço novo, o espaço que quer educá-los. Como operar com as imagens dessas crianças? Como pensar nossas práticas, uma escola, currículos, com o que essas crianças nos contam com suas imagens?

Pode a imagem desformar a educação nesse espaço?

Esse incomodo é dialogado por Chisté e Leite (2014) que também ocuparam o espaço da Educação Infantil com imagens. Ao discutirem as produções imagéticas dessas crianças, os autores enfatizam a necessidade de uma formação infante, de multiplicidades, sem gaiolas orientadas pelo certo e 0 errado. E as imagens são potência para esse movimento.

Talvez as imagens/filmagens, as crianças, as infâncias nos ajude a pensar na possibilidade de uma formação docente que seja infantil, uma formação de professores da infância. Uma formação de professor, que sendo infantil, não pretende representar, nem apresentar sua função, que não fecha questão sobre qualquer assunto, que não cria espaços onde verdades circulam, que não dita regras, nem modos de pensar e caminhos a seguir. Que fuja da docilização dos corpos e dos corpos produzidos. Mas que abra linhas de fugas, inúmeras possibilidades, modos de afetação, que desloque-se, desnuda-se, que enxergue as crianças, suas singularidades, suas potências, que enxergue, veja, se mobilize, se afete com a própria infância das coisas, 
com a nossa infância, com a nossa condição infante. Uma formação de professor que fuja dos modelos dados, de um devir definido, de uma infantilização docente (CHISTÉ; LEITE, 2014, p. 4063).

A partir disso, nos propomos a pensar uma (des)formação de professores, em que as crianças e suas imagens sejam vistas como são: potência criadora e inventiva, que nos apresentam o presente, o momento, delas e nosso, dentro de um espaço escolar que pode ser também espaço de infância, de gaguejo, de encantamento.

Nessa mesma direção, entendemos que o currículo da Educação Infantil também pode ser pensando com elas. Currículo até então homogêneo, que opera em uma mesma direção. Currículo que muito infantiliza, que pouco é feito de infância. Currículo que dociliza. Segundo Kohan (2003), é preciso pensar então em um currículo repleto de infância, educado por ela e não que busque educá-la. De novo, é Barros (2015) quem nos indica o caminho:

Mas eu estava a pensar em achadouros de infâncias. Se a gente cavar um buraco ao pé da goiabeira do quintal, lá estará um guri ensaiando subir na goiabeira. Se a gente cavar um buraco ao pé do galinheiro, lá estará um guri tentando agarrar no rabo de uma lagartixa. Sou hoje um caçador de achadouros de infância. Vou meio dementado e enxada às costas a cavar no meu quintal vestígios dos meninos que fomos (p. 124).

As imagens dessas crianças podem então nos ajudar a encontrar esses achadouros de infância (e se não encontrarmos, vivenciar essa procura). As imagens das crianças podem nos possibilitar buscar infâncias, descobertas, fazeres, risadas, novidades. Talvez essas imagens, essa outra língua, essa paixão em forma de produção, possa nos fazer entender que os professores e crianças precisam se misturar, como as tintas de um desenho produzido na infância. Assim, nos parece que problematizar a partir/com essas imagens diz de uma sensibilidade de perceber nesses encontros a necessidade de movimentos invertidos na Educação Matemática. Necessidade de perceber que talvez o mundo precise de mais afeto, mais inventividade, e não de uma Educação Matemática que dá formas, mas de uma Educação Matemática que é desformada pela infância.

\section{ENFIM, UM DESFORMAR DE RESTOS QUE NOS AFETAM E NOS LEVAM A RESISTIR}

Três personagens me ajudaram a compor estas memórias. Quero dar ciência delas. Uma, a criança; dois, os passarinhos; três, os andarilhos. A criança me deu a semente da palavra. Os passarinhos me deram desprendimento das coisas da terra. E os andarilhos, a preciência da natureza de Deus. Quero falar primeiro dos andarilhos, do uso em primeiro lugar que eles faziam da ignorância. Sempre eles sabiam tudo sobre 0 nada. E ainda multiplicavam o nada por zero o que lhes dava uma linguagem de chão. Para nunca saber onde chegavam. E para chegar sempre de surpresa. Eles não afundavam estradas, mas inventavam 
caminhos. Essa a pré-ciência que sempre vi nos andarilhos. Eles me ensinaram a amar a natureza.

Bem que eu pude prever que os que fogem da natureza um dia voltam para ela. Aprendi com os passarinhos a liberdade. Eles dominam o mais leve sem precisar ter motor nas costas. E são livres para pousar em qualquer tempo nos lírios ou nas pedras - sem se machucarem. E aprendi com eles ser disponível para sonhar. 0 outro parceiro de sempre foi a criança que me escreve (BARR0S, 2015, p. 127).

Quem compôs comigo as histórias que contei aqui?

Já é madrugada de segunda e estou olhando para 0 teto. 0 sono não veio e talvez não venha. Há muita coisa para pensar. Eu poderia estar tentando dimensionar tudo o que vi. Poderia estar tentando classificar o canto dessas crianças que cantaram como sabiás. As crianças me contaram muitas histórias...sobre a escola, sobre coisas que fazem fora dela, sobre brincadeiras, sobre a sala de aula, sobre as matemáticas... Nos vídeos foram passarinhos, livres, sonhadoras. Elas, com seus corpos diminutos resistiram a pergunta: 0 que é matemática? Elas com suas pernas curtas correndo e correndo e gargalhando, resistiram e mostraram: veja, sou criança, mas também passarinho, posso pousar em qualquer lugar. E me convidaram: voe comigo, mas se tiver medo, me acompanhe caminhando. De qualquer forma, ande ou voe, mas resista!

Talvez a escola, a educação possam resistir também, junto com as crianças, junto com a infância. Talvez a educação, a escola, talvez nós, possamos também inventar caminhos com as crianças. Educação e escola que podem ser o que quiserem também, voando ou caminhando, resistentes, infantes.

Talvez eu também possa. Talvez agora eu esteja começando a adivinhar, sem nomear, sem traçar rota, apenas sendo afetada. Talvez aqui, este momento, eu comece a ser andarilha.

Figura 7 - Sou passarinho, sou sabiá

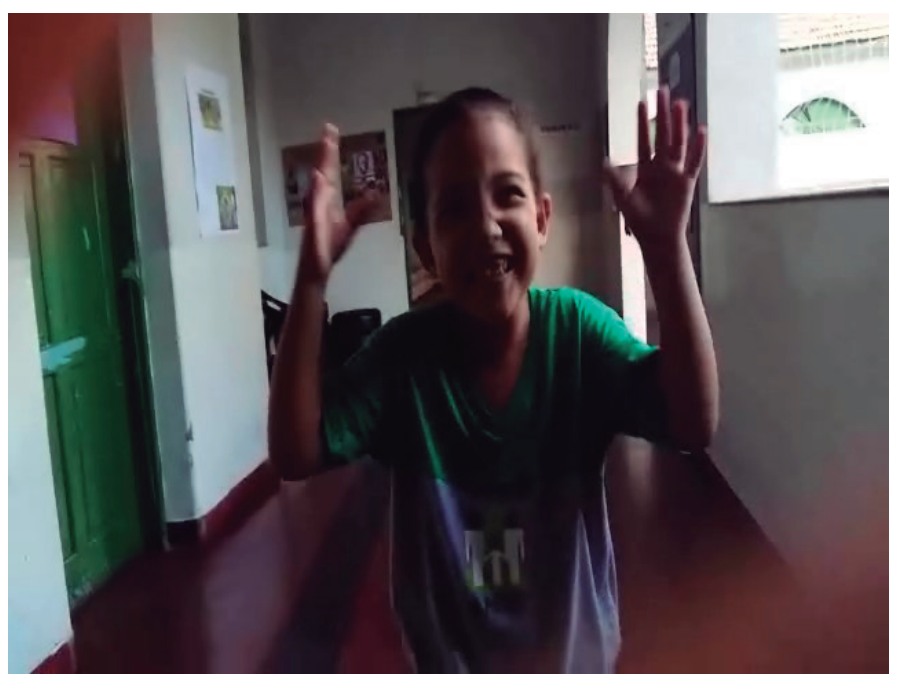

Fonte: Das Autoras 


\section{AGRADECIMENTOS}

À Coordenação de Aperfeiçoamento de Pessoal de Nível Superior - Brasil (CAPES) - Código de Financiamento 001, bolsa de doutorado.

\section{REFERÊNCIAS}

BARROS. M. Memórias Inventadas a segunda infância. São Paulo: Planeta, 2006.

Meu quintal é maior do que o mundo. Rio de Janeiro: Objetiva, 2015.

BRITO, M. dos R. de. Da formação à deformação: para além da fundamentação. IXTLI: Revista Latinoamericana de Filosofía de la Educación, v. 3, n. 5, p. 85-104, 2016.

CHISTÉ, B. S. Devir - criança da matemática: experiências educativas infantis imagéticas. 2015. $106 \mathrm{f}$. Tese de Doutorado (Doutorado em Educação Matemática) - Universidade Estadual Paulista Júlio de Mesquita Filho, Rio Claro - SP, 2015.

CHISTÉ, B. S.; LEITE, C. D. P. Imagens de crianças como indícios: esboços de formação de professores da infância. In: Anais... II Congresso Nacional de Professores e XII Congresso Estadual sobre Formação de Educadores. São Paulo: UNESP; PROGRAD, 2014. p. 4054-4064 Disponível em: <http://hdl.handle.net/11449/141620>. Acesso em 01 de abri. de 2020.

CLARETO, S. M. Matemática como acontecimento na sala de aula. Anais... In: Reunião Nacional da ANPED (Sistema Nacional de Educação e Participação Popular: desafios para as políticas educacionais), 2008. ANAIS: Reunião nacional da ANPED (Sistema Nacional de Educação e Participação Popular: Desafios para as Políticas Educacionais). Goiânia/ GO: 2013.

COSTA, L. B. Cartografia: uma outra forma de pesquisar. Revista digital do LAV, v. 7, n. 2, p. 66-77, 2014.

KOHAN, W. O. Imagens da infância para (re) pensar o currículo. Revista Sul-americana de filosofia e educação, Brasília, Universidade de Brasília, s/v, n. 1, p. 1-9, 2003.

. Infância. Entre Educação e Filosofia. Belo Horizonte: Autêntica, 2005.

LEITE, C. D. P. Cinema, Educação e Infância: Fronteiras entre Educação e Emancipação. Fermentario: Instituto de Educación, Facultad de Humanidades y Ciencias de la Educación, Universidad de la República, v. 2, n. 7, p. 14, 2013.

MORAES, M. C. Complejidad y currículo: por una nueva relación. Polis (Santiago), v. 9, n. 25, p. 289-311, 2010.

MEDEIROS, A. S. de. Devires de imagens: atitudes e matemática(s) construídas e praticadas por um grupo de crianças. 124 f. Dissertação (Mestrado em Educação Matemática) - Universidade Federal de Mato Grosso do Sul, Campo Grande, 2018.

RIBETTO, A. Experiência, experimentações e restos na escrita acadêmica. In: CALLAI, Cristiana; RIBETTO, A. (Org.). Uma escrita acadêmica outra: ensaios, experiências e invenções. 1ed. Rio de Janeiro: Lamparina/FAPERJ, v. 1, p. 58-67, 2016. 
RIBETTO A.; DIAS, R. Micropolítica e uma aposta ética, estética e política de formar professores pela invenção. Revista Educação e Cultura Contemporânea, v.17, n. 47, p. 209-229, 2020.

ROLNIK, S. Pensamento, corpo e devir: uma perspectiva ético/estético/política no trabalho acadêmico. Cadernos de subjetividade, v. 1, n. 2, p. 241-251, 1993.

WUNDER, A. Restos quase mortais: fotografia, acontecimento e escola. In: $31^{\text {a }}$ Reunião Anual da Associação de Pós-graduação e Pesquisa em Educação (ANPED), 2008, Caxambu. ANAIS da 31ª Reunião Anual da Associação de Pós-graduação e Pesquisa em Educação (ANPED), v. 1. p. 245-277, 2008.

RECEBID0 EM: 25 jun. 2020

CONCLUÍDO EM: 07 out. 2020 